\title{
A Domain-Specific Terminology for Retinopathy of Prematurity and Its Applications in Clinical Settings
}

\author{
Yinsheng Zhang $\mathbb{D}^{1,2}$ and Guoming Zhang $\mathbb{D}^{3}$ \\ ${ }^{1}$ School of Management Science and E-Business, Zhejiang Gongshang University, Hangzhou, Zhejiang 310018, China \\ ${ }^{2}$ Contemporary Business and Trade Research Center of Zhejiang Gongshang University, Hangzhou, Zhejiang 310018, China \\ ${ }^{3}$ Pediatric Retinal Surgery Department, Shenzhen Key Ophthalmic Laboratory, Shenzhen Eye Hospital and The Second Affiliated \\ Hospital of Jinan University, Guangzhou 518040, China
}

Correspondence should be addressed to Yinsheng Zhang; zhangys@zjgsu.edu.cn and Guoming Zhang; zhang-guoming@163.com Received 28 July 2017; Accepted 19 February 2018; Published 18 April 2018

Academic Editor: Van C. Lansingh

Copyright (c) 2018 Yinsheng Zhang and Guoming Zhang. This is an open access article distributed under the Creative Commons Attribution License, which permits unrestricted use, distribution, and reproduction in any medium, provided the original work is properly cited.

\begin{abstract}
A terminology (or coding system) is a formal set of controlled vocabulary in a specific domain. With a well-defined terminology, each concept in the target domain is assigned with a unique code, which can be identified and processed across different medical systems in an unambiguous way. Though there are lots of well-known biomedical terminologies, there is currently no domainspecific terminology for ROP (retinopathy of prematurity). Based on a collection of historical ROP patients' data in the electronic medical record system, we extracted the most frequent terms in the domain and organized them into a hierarchical coding system-ROP Minimal Standard Terminology, which contains 62 core concepts in 4 categories. This terminology has been successfully used to provide highly structured and semantic-rich clinical data in several ROP-related applications.
\end{abstract}

\section{Introduction}

Retinopathy of prematurity (ROP) is a vaso-proliferative retinal disease affecting premature and low birth-weight infants. It is one of the main causes of children blindness worldwide. With the advancement of perinatal care quality, the survival rate of premature infants increases steadily, making ROP an unneglectable problem in both developed and developing countries. In China alone, there are about two million premature babies born annually. The incidence rate of ROP among premature babies is about $10 \%$ [1]. A conservative estimate of annual ROP infants is 200,000 . The timely screening and intervention have become a huge problem worldwide.

To address this problem, four years ago, we initiated the CMS-R (Case Management System for ROP) project. This system is designed to support effective clinical data management and provide cross-regional telemedicine of ROP screening. One prerequisite of CMS-R is a well-defined domain-specific terminology. Such a terminology is essential for achieving SDE (structured data entry) and generating highly structured clinical data. It can also be used for future data exchange with external health information systems. This paper will introduce a ROP-specific terminology developed for CMS-R.

\section{Related Work}

Terminology, a.k.a. controlled vocabulary, is a collection of terms with explicitly defined meanings and unique codes in a specific domain. In the medical domain, there are hundreds of openly published terminologies. Readers may refer to https://www.nlm.nih.gov/research/umls/sourcereleasedocs/ index.html for a list of medical terminologies. The following are some of the most widely used biomedical terminologies.

ICD (International Classification of Diseases [2]) organizes disease terms in a hierarchical style according to their semantic relations. It is widely used in EMRS (Electronic Medical Record System) and HIS (Hospital Information System) as diagnostic codes. LOINC (Logical Observation Identifiers Names and Codes) [3] is a terminology of tests, measurements, and observations, which is widely used in LIS (Laboratory Information System). CPT (Current 
TABLE 1: Term categories.

\begin{tabular}{|c|c|c|c|c|}
\hline Alias 1: English & Alias 2: Chinese & Alias 3: Japanese & Code & Coding system \\
\hline Diagnosis & 诊断 & 診断 & $\mathrm{D}$ & ROP_MST \\
\hline Treatment & 治疗 & 治療 & $\mathrm{T}$ & ROP_MST \\
\hline Examination & 检查 & 検査 & $\mathrm{E}$ & ROP_MST \\
\hline Laterality & 眼别 & 目の左右差 & $\mathrm{L}$ & ROP_MST \\
\hline
\end{tabular}

Table 2: Diagnostic terms.

\begin{tabular}{|c|c|c|c|c|}
\hline Alias 1: English & Alias 2: Chinese & Alias 3: Japanese & Code & Coding system \\
\hline Diagnosis & 诊断 & 診断 & $\mathrm{D}$ & ROP_MST \\
\hline Retina with completed vascularization & 视网膜完全血管化 & 網膜血管完全に成長した & D000 & ROP_MST \\
\hline Immature retina & 视网膜发育不全 & 網膜血管形成不全 & D001 & ROP_MST \\
\hline Zone & 分区 & ゾーン & D001.Z & ROP_MST \\
\hline Zone I & 1 区 & ゾーン I & D001.Z001 & ROP_MST \\
\hline Zone II & 2 区 & ゾーン II & D001.Z002 & ROP_MST \\
\hline Zone III & 3 区 & ゾーン III & D001.Z003 & ROP_MST \\
\hline Plus disease & Plus 病变 & プラス病変 & D001.P & ROP_MST \\
\hline+ & + & + & D001.P001 & ROP_MST \\
\hline++ & ++ & ++ & D001.P002 & ROP_MST \\
\hline+++ & +++ & +++ & D001.P003 & ROP_MST \\
\hline ROP & 早产儿视网膜病 & 未熟児網膜症 & D002 & ROP_MST \\
\hline Acute ROP & 急性 ROP & 急性 ROP & D002.A001 & ROP_MST \\
\hline Zone & 分区 & ゾーン & D002.A001.Z & ROP_MST \\
\hline Zone I & 1 区 & ゾーン I & D002.A001.Z001 & ROP_MST \\
\hline Zone II & 2 区 & ゾーン II & D002.A001.Z002 & ROP_MST \\
\hline Zone III & 3 区 & ゾーン III & D002.A001.Z003 & ROP_MST \\
\hline Stage & 分期 & ステージ & D002.A001.S & ROP_MST \\
\hline Stage 1 & 1 期 & ステージ 1 & D002.A001.S001 & ROP_MST \\
\hline Stage 2 & 2 期 & ステージ 2 & D002.A001.S002 & ROP_MST \\
\hline Stage 3 & 3 期 & ステージ 3 & D002.A001.S003 & ROP_MST \\
\hline Stage 4 & 4 期 & ステージ 4 & D002.A001.S004 & ROP_MST \\
\hline Stage $4 \mathrm{~A}$ & $4 \mathrm{~A}$ 期 & ステージ $4 \mathrm{~A}$ & D002.A001.S004A & ROP_MST \\
\hline Stage4B & 4B 期 & ステージ 4B & D002.A001.S004B & ROP_MST \\
\hline Stage 5 & 5 期 & ステージ 5 & D002.A001.S005 & ROP_MST \\
\hline Plus disease & Plus 病变 & プラス病変 & D002.A001.P & ROP_MST \\
\hline+ & + & + & D002.A001.P001 & ROP_MST \\
\hline++ & ++ & ++ & D002.A001.P002 & ROP_MST \\
\hline+++ & +++ & +++ & D002.A001.P003 & ROP_MST \\
\hline Type 1 ROP & 1 型 ROP & I 型未熟児網膜症 & D002.A001.1 & ROP_MST \\
\hline Type 2 ROP & 2 型 ROP & II 型未熟児網膜症 & D002.A001.2 & ROP_MST \\
\hline Threshold ROP & 阈值 $\mathrm{ROP}$ & 閾值未熟児網膜症 & D002.A001.3 & ROP_MST \\
\hline APROP & 急进型后极部早产儿视网膜病 & 積極的な後方未熟児網膜症 & D002.A001.4 & ROP_MST \\
\hline Regression of ROP & 退行性 ROP & 未熟児網膜変性症 & D002.A002 & ROP_MST \\
\hline Posterior retina & 后极 & 網膜後極部 & D002.A002.Z001 & ROP_MST \\
\hline Peripheral retina & 周边 & 網膜周辺部 & D002.A002.Z003 & ROP_MST \\
\hline Reactivation of anti-VEGF agent & 抗 VEGF 治疗后复发 & 抗 VEGF 剂の再活性化 & D003 & ROP_MST \\
\hline Complications of ROP surgery & ROP 术后并发症 & ROP 合併症 & D004 & ROP_MST \\
\hline Postoperative condition & ROP 术后 & ROP 手術の歴史 & D005 & ROP_MST \\
\hline Vision & 视力 & 視力 & D00F.V & ROP_MST \\
\hline Normal vision & 正常视力 & 正常視力 & D00F.V001 & ROP_MST \\
\hline Subnormal vision & 低视力 & 異常視力 & D00F.V002 & ROP_MST \\
\hline Blindness & 失明 & 失明 & D00F.V003 & ROP_MST \\
\hline
\end{tabular}

APROP = aggressive posterior retinopathy of prematurity; VEGF = vascular endothelial growth factor. 
TABLE 3: Treatment terms.

\begin{tabular}{|c|c|c|c|c|}
\hline Alias 1: English & Alias 2: Chinese & Alias 3: Japanese & Code & Coding system \\
\hline Treatment/management & 治疗 & 治療 & $\mathrm{T}$ & ROP_MST \\
\hline Regular follow-up & 定期复查 & 定期的なレビュー & T001 & ROP_MST \\
\hline Laser photocoagulation & 激光光凝术 & レーザ一光凝固 & T002 & ROP_MST \\
\hline Intravitreal injection & 玻璃体腔注药术 & ケナコルト硝子体内注入 & T004 & ROP_MST \\
\hline Ranibizumab & 雷珠单抗 & ラニビズマブ & T004.M001 & ROP_MST \\
\hline Bevacizumab & 贝伐单抗 & ベバシズマブ & T004.M002 & ROP_MST \\
\hline Conbercept & 康柏西普 & コンバーセル & T004.M003 & ROP_MST \\
\hline Vitreoretinal surgery & 玻璃体视网膜手术 & 網膜硝子体手術 & T003 & ROP_MST \\
\hline
\end{tabular}

TABLE 4: Examination terms.

\begin{tabular}{|c|c|c|c|c|}
\hline Alias 1: English & Alias 2: Chinese & Alias 3: Japanese & Code & Coding system \\
\hline Examination & 检查 & 検査 & $\mathrm{E}$ & ROP_MST \\
\hline Metabolomics test & 代谢组学检查 & メタボロミクステスト & E008 & ROP_MST \\
\hline Imaging & 影像学检查 & イメージング & E010 & ROP_MST \\
\hline Fundus photograph & 眼底照相 & 眼底写真 & E010.IM01 & ROP_MST \\
\hline FFA & 眼底荧光素血管造影 & 眼底フルオレセイン造影 & E010.IM02 & ROP_MST \\
\hline $\mathrm{CT}$ & $\mathrm{CT}$ & $\mathrm{CT}$ & E010.IM03 & ROP_MST \\
\hline MRI & 核磁共振 & MRI & E010.IM04 & ROP_MST \\
\hline Corneal topography & 角膜地形图 & 角膜形状解析 & E010.IM05 & ROP_MST \\
\hline OCT & OCT & OCT & E010.IM06 & ROP_MST \\
\hline US & 超声 & 超音波検査 & E010.IM08 & ROP_MST \\
\hline ERG & 视网膜电图 & 網膜電記録 & E015 & ROP_MST \\
\hline VEP & 视觉诱发电位 & 視覚誘発電位 & E016 & ROP_MST \\
\hline
\end{tabular}

FFA = fundus fluorescein angiography; $\mathrm{CT}=$ computed tomography; $\mathrm{MRI}=$ magnetic resonance imaging; OCT =optical coherence tomography; US = ultrasonography; ERG = electroretinography; VEP = visual evoked potential.

Procedural Terminology) [4] is a medical code set for medical services, surgeries, and procedures. CPT terms are often used for billing items in HIS. RxNorm [5] is a drug terminology, which is widely used in CPOE (Computerized Physician Order Entry). MTHMST (Metathesaurus Minimal Standard Terminology Digestive Endoscopy) [6] is a domain-specific in terminology for the endoscopy specialty, authored by ESGE (European Society of Gastrointestinal Endoscopy). GO (Gene Ontology) [7] is a terminology for molecular function, biological process, and cellular component. HPO (Human Phenotype Ontology) [8] provides a well-defined set of terms that describe human phenotypic abnormalities. SNOMED-CT (Systematized Nomenclature of MedicineClinical Terms) [9] is a rather comprehensive medical terminology, which uses a formally defined medical ontology as the backbone for concepts and terms. UMLS (Unified Medical Language System) [10] metathesaurus is a project initiated by US National Library of Medicine, aiming at mapping concepts in existing terminologies into a comprehensive metathesaurus ontology. The current UMLS version has integrated more than 200 existing terminologies.

Most biomedical terminologies are focused on a specific domain or developed for a special purpose. When it comes to a specific domain, such specialized terminologies have more advantages than general-purposed ones: (1) Expressiveness: some fine-grained concepts in a specific domain may not be directly available in general-purposed terminologies. For example, "Type 1 ROP" is a special concept in the ROP domain and is difficult to find an off-the-shelf item in existing terminologies. (2) Efficiency: a specially tailored terminology can be more coherent and efficient in expressing certain domain concepts. In such cases, general-purposed medical terminologies may have to use complex postcoordinated expressions or combinations of multiple terms. (3) Reasoning and inference: specialized terminologies can use hierarchical coding systems to facilitate reasoning and semantic query. For example, H35.0 (background retinopathy and retinal vascular changes) and H35.1 (retinopathy of prematurity) in ICD-10 are sibling concepts under the common parent concept $\mathrm{H} 35$ (other retinal disorders).

Currently, there is no specially tailored terminology for ROP, which has hindered the effective application of ROP-related systems. In this manuscript, we will introduce a domain-specific terminology for ROP and demonstrate several used cases of ROP-related applications.

\section{Terminology Development}

3.1. Clinical Settings and Materials. This study is conducted in Shenzhen Eye Hospital (SEH), a 200-bedded class III 
TABLE 5: Laterality terms.

\begin{tabular}{lcccc}
\hline $\begin{array}{l}\text { Alias 1: } \\
\text { English }\end{array}$ & $\begin{array}{c}\text { Alias 2: } \\
\text { Chinese }\end{array}$ & $\begin{array}{c}\text { Alias 3: } \\
\text { Japanese }\end{array}$ & Code & $\begin{array}{c}\text { Coding } \\
\text { system }\end{array}$ \\
\hline Laterality & 眼别 & 目の左右差 & L & ROP_MST \\
OD & 右眼 & 右目 & L001 & ROP_MST \\
OS & 左眼 & 左目 & L002 & ROP_MST \\
OU & 双眼 & 両方の目 & L003 & ROP_MST \\
\hline
\end{tabular}

$\mathrm{OD}=$ oculus dexter (right eye); $\mathrm{OS}=$ oculus sinister (left eye); $\mathrm{OU}=$ oculus utro (both eyes).

specialized hospital in China. SEH has long been providing ROP screening services for peripheral partner hospitals, including Shenzhen People's Hospital, Peking University Shenzhen Hospital, University of Hong Kong-Shenzhen Hospital, Shenzhen Maternal and Child Health Hospital, Meizhou People's Hospital (Guangdong Province, China), and Puning People's Hospital (Fujian Province, China). With more than 10 years of experience, SEH has accumulated more than 20,000 ROP infants' clinical data. Based on these historical data, we made a term frequency analysis (detailed analysis data can be downloaded from http://ropd.brahma. top/Assets/TermFrequency.xls.) to identify most frequently used terms in the ROP domain.

From the analysis, a total of 37,070 valid text strings are extracted, which correspond to 752 distinct narrative terms. We then sort the terms by their frequencies in descending order, to determine which terms are used most often. As the distinctive term number is not huge (752), the ophthalmologists manually coordinated (e.g., multiple free-text narrations of a same concept) these terms and reorganized them into a hierarchical concept tree.

3.2. The ROP_MST Terminology. Based on the above analysis, we built a hierarchical terminology-ROP_MST (ROP Minimal Standard Terminology), which contains 62 ROPrelated core concepts in 4 primary categories (i.e., diagnosis, treatment, examination, and laterality). Each concept has a unique code and multiple aliases (equivalent narratives in different languages). The encoding rule is similar to ICD, that is, the code of a subordinate concept is prefixed by its superior concept code. For example, intravitreal injection (T004) is a parent concept of Ranibizumab intravitreal injection (T004.M001). Such encoding rule facilitates conceptlevel information retrieval and semantic reasoning. Users may refer to Tables $1-5$ for the terminology.

\section{Applications}

4.1. Structured Data Entry. A basic usage of ROP_MST is SDE, which ensures highly structured and semantic-rich clinical data for ROP-related information systems. In CMS-R (demo version: http://ropd.brahma.top), SDE is widely used. As shown in Figure 1, the diagnostic tree is arranged by terms' conceptual hierarchy. Users can click the triangle icon to expand or collapse branches. When user clicks a child node, all parent nodes along its path will also be selected. User can express complex conditions by selecting multiple nodes. For example, "ROP Zone II Stage

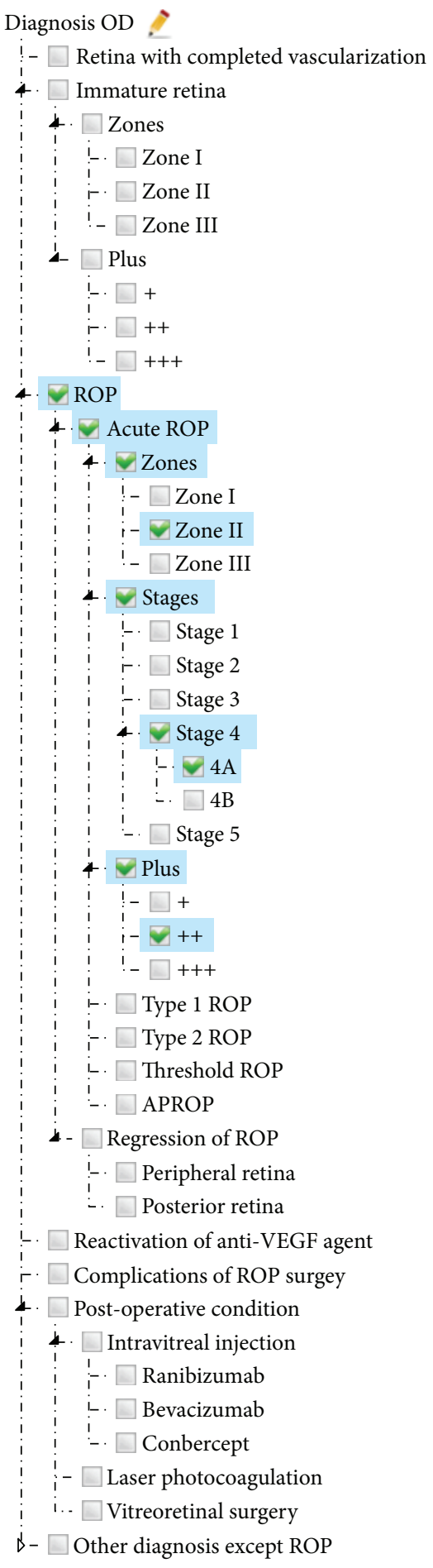

FIgURE 1: SDE (Structured Data Entry) for diagnosis in CMS-R.

4A ++" can be expressed by D002.A001, D002.A001.Z002, D002.A001.S004A, and D002.A001.P002. When user saves patient data, the codes of the selected terms will be persisted in the server-side database. As each concept/term is explicitly assigned to a unique code, the potential ambiguity and chaos that arise from free-text input can be prevented.

4.2. Advanced Search. Information retrieval is a common task for clinical information systems, for example, searching 


\section{LabelR Home Gallery Toolv Wiki About}

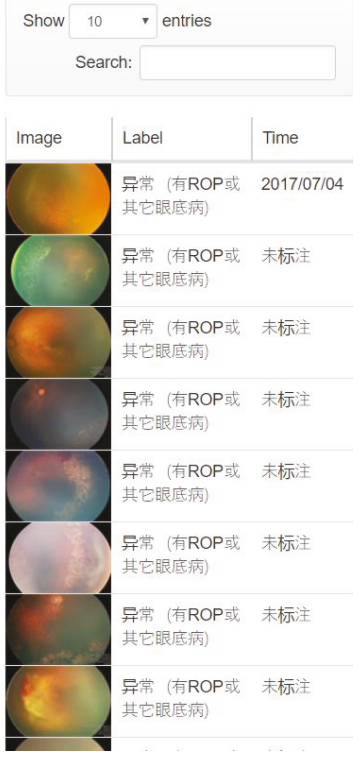

MbwW4LSD3kyh7bNQORw2RQ.jpg

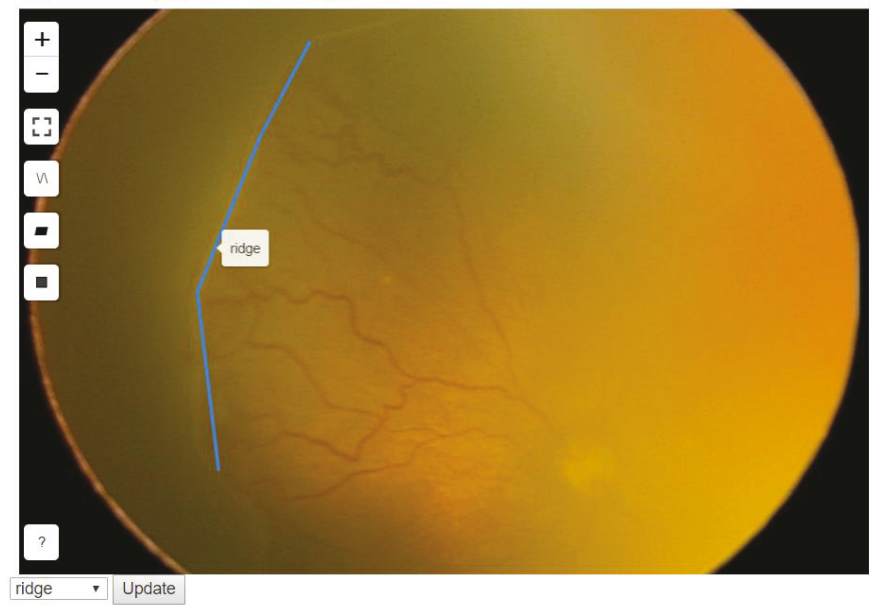

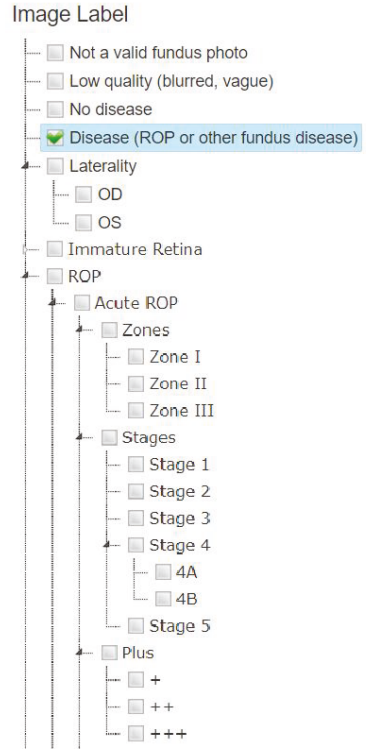

FIGURE 2: Fundus image labeling tool based on ROP_MST.

qualified patients to be included in randomized clinical trials. As ROP_MST codes imply relations between subordinate and superior concepts, we can use it for advanced search. For instance, if the user wants to search all patients treated by intravitreal injection (T004), no matter the injection is Ranibizumab (T004.M001), Bevacizumab (T004.M002), or Conbercept, one simple search rule "[VisitTreatmentCode] $==$ T004\%" would suffice ("\%" is a wild card and "T004\%" means any code starting with "T004"). In contrast, the traditional way based on plain text matching usually requires users to enumerate all subordinate literal cases and write complex search patterns. Readers may access the advanced search function in CMS-R (http://ropd.brahma. top/search).

4.3. Reasoning to Get the Most Severe Diagnoses. Getting the most severe diagnosis based on multiple visit diagnoses is a very common task in ROP research. Traditionally, this job is done manually by physicians. With the help of ROP_MST, this can be automated by reasoning over the diagnosis codes. For instance, as ROP_MST defines fine-grained terms (i.e., zones, stages, and plus) for acute ROP (D002.A001), the severity of acute ROP can be judged by combining zone codes (D002.A001.Z001 > D002.A001.Z002 > D002.A001. Z003), stage codes (D002.A001.S001 < D002.A001.S002< D002.A001.S003 < D002.A001.S004 < D002.A001.S005), and plus codes (D002.A001.P001 < D002.A001.P002 < D002.A001. P003). In CMS-R, an "induced most severe diagnosis" algorithm was designed to relieve users of manual data inputs.

4.4. Fundus Image Labeling Tool for Deep Learning. Computer-aided diagnosis based on fundus photography is a promising technology in ROP screening and telemedicine. Since the beginning of 2017, we have been using deep learning techniques to train a classifier to identify whether a fundus image has ROP or not. One prerequisite resource is a training set with high-quality class labels, and a "LabelR (Labeling Tool for ROP, http://label.brahma.top)" system was developed. LabelR allows user to assign multiple unambiguous and fine-grained diagnostic labels from ROP_MST to each fundus image (Figure 2).

\section{Conclusions and Discussions}

The first version of ROP_MST was designed in 2013 and has since then been evolving to better suit pediatric ophthalmologists' needs. Compared to other coding systems, the unique strength of ROP_MST is its specialty and domain orientation. All terms in ROP_MST are systematically organized by a hierarchical coding mechanism and are much easier for ROP-related applications. During research, we also encountered several issues that require concerns or future research.

5.1. Using Clustering Algorithms to Aggregate Terms. In building ROP_MST, the disambiguation of multiple literal strings for the same concept is performed manually by pediatric ophthalmologists. However, for other future ophthalmology terminologies, the total number of literal strings could be larger (say tens of thousands). For such cases, the manual operation would become unrealistic. A feasible solution would be designing a string similarity function (e.g., Levenshtein distance) and a text clustering algorithm (e.g., $k$-means).

5.2. Mapping with Existing Coding Systems. In order to integrate existing biomedical data encoded by traditional coding systems, it is essential to implement a terminology translation service. This service aims to map existing coding systems 
to ROP_MST, which could be a rather complicated task due to the heterogeneity between terminologies. Although several concepts can be directly mapped (e.g., "retinopathy of prematurity" (H35.1, ICD-10) ↔ "ROP” (D002) and "stage of retinopathy in retinopathy of prematurity" (422746009, SNOMED CT)↔ "ROP stage" (D002.A001.S)), others may involve the mapping of multiple-concept combinations between different terminologies.

\section{Conflicts of Interest}

The authors declare that there is no conflict of interest regarding the publication of this paper.

\section{Acknowledgments}

The authors would like to thank the clinical staff in SEH who helped in analyzing the historical data and refining clinical requirements. This study is supported by the National Natural Science Foundation of China (71373117, 71433006, 91746202), Shenzhen Science and Technology Innovation Committee, China (201602293000443 and JCY20140414114853651), and Health and Family Planning Commission of Shenzhen Municipality, China (201501038).

\section{References}

[1] Q. Li, Z. Wang, R. Wang, H. Tang, H. Chen, and Z. Feng, "A prospective study of the incidence of retinopathy of prematurity in China: evaluation of different screening criteria," Journal of Ophthalmology, vol. 2016, Article ID 5918736, 8 pages, 2016.

[2] M. L. Peery, "International classification of diseases," in Encyclopedia of Special Education, John Wiley \& Sons, Inc., 2008.

[3] D.-A. Jurcau, V. Stoicu-Tivadar, and A. Serban, "Using modern technologies to facilitate translating logical observation identifiers names and codes," in Soft Computing Applications: Proceedings of the 6th International Workshop Soft Computing Applications, Volume 1, V. E. Balas, L. C. Jain, and B. Kovačević, Eds., pp. 219-229, Cham: Springer International Publishing, 2016.

[4] J. A. Hirsch, T. M. Leslie-Mazwi, G. N. Nicola et al., "Current procedural terminology: a primer," Journal of NeuroInterventional Surgery, vol. 7, no. 4, pp. 309-312, 2015.

[5] J. Staab and A. Karnopp, "Mapping medication orders to RxNorm concepts," Journal of Patient-Centered Research and Reviews, vol. 3, no. 3, p. 223, 2016.

[6] L. Aabakken, A. N. Barkun, P. B. Cotton et al., "Standardized endoscopic reporting," Journal of Gastroenterology and Hepatology, vol. 29, no. 2, pp. 234-240, 2014.

[7] The Gene Ontology Consortium, "Gene ontology consortium: going forward," Nucleic Acids Research, vol. 43, no. D1, pp. D1049-D1056, 2015.

[8] T. Groza, S. Köhler, D. Moldenhauer et al., "The human phenotype ontology: semantic unification of common and rare disease," American Journal of Human Genetics, vol. 97, no. 1, pp. 111-124, 2015.
[9] T. Benson and G. Grieve, Principles of Health Interoperability: SNOMED CT, HL7 and FHIR: Springer, 2016.

[10] K. Saravana Kumar and K. Deepa, "Medical query expansion using UMLS," Indian Journal of Science and Technology, vol. 9, no. 14, 2016. 


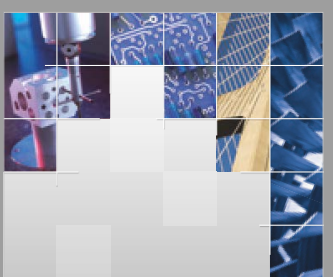

\section{Enfincering}
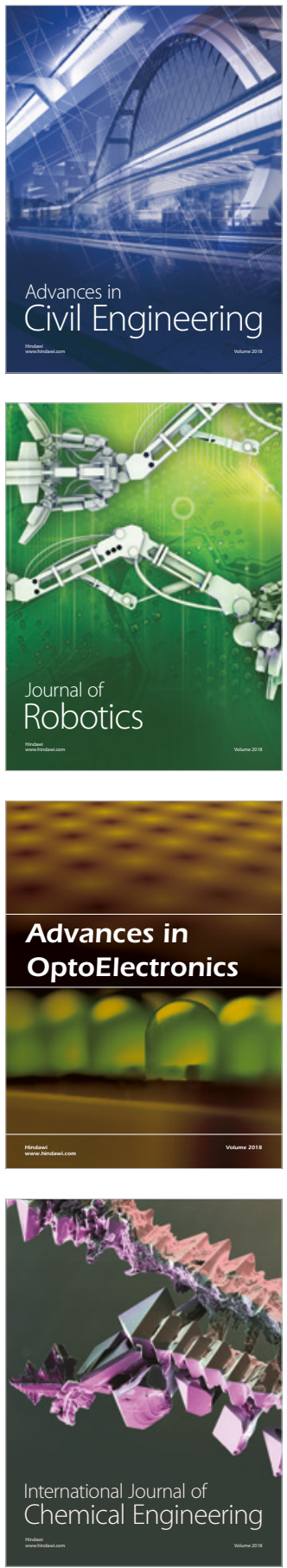

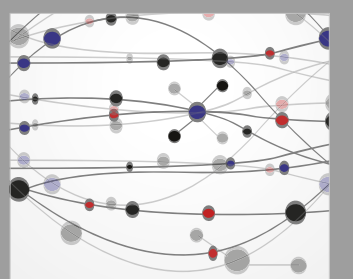

\section{Rotating \\ Machinery}

The Scientific World Journal

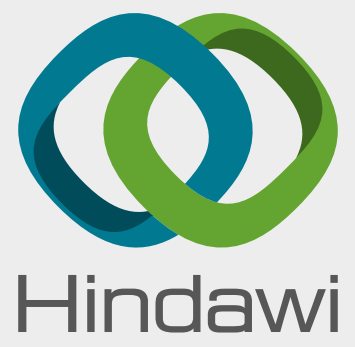

Submit your manuscripts at

www.hindawi.com
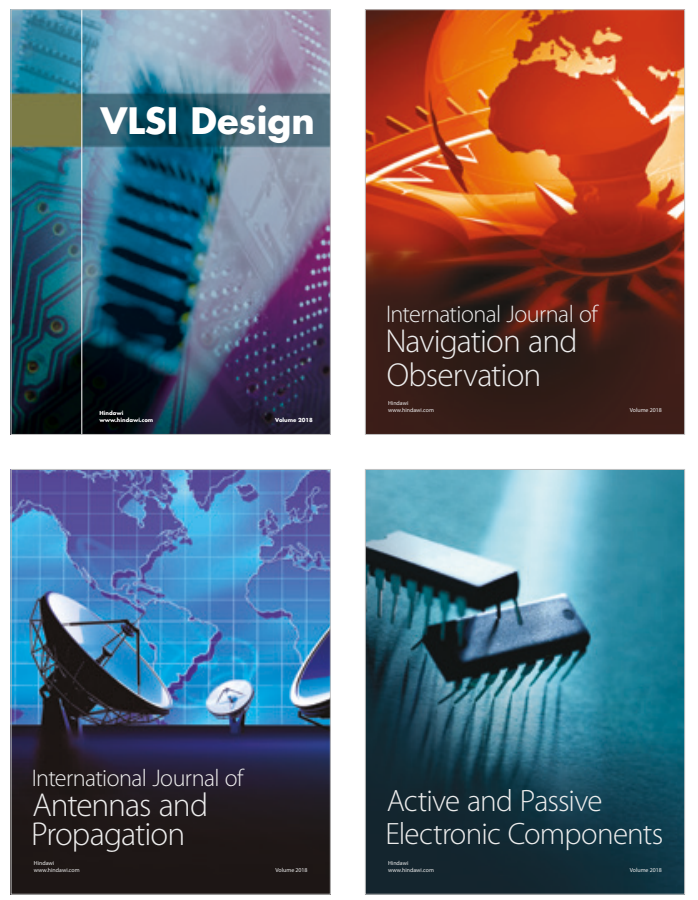
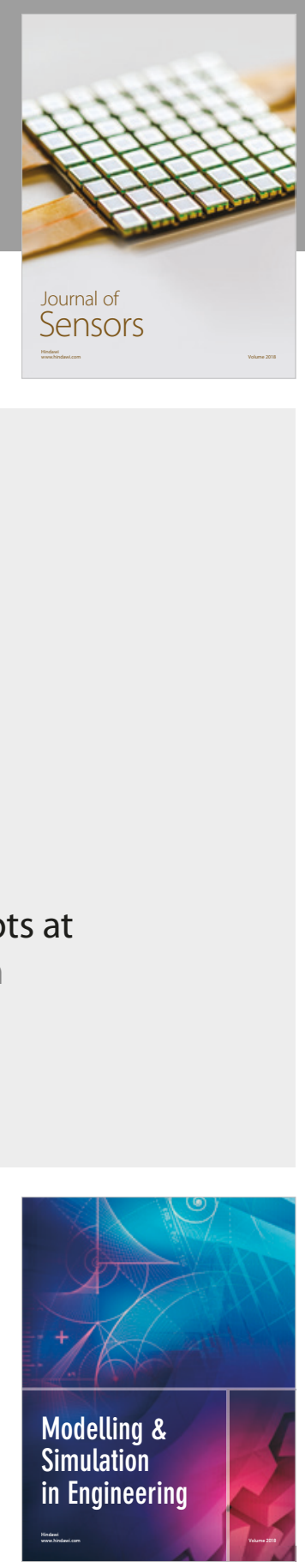

\section{Advances \\ Multimedia}
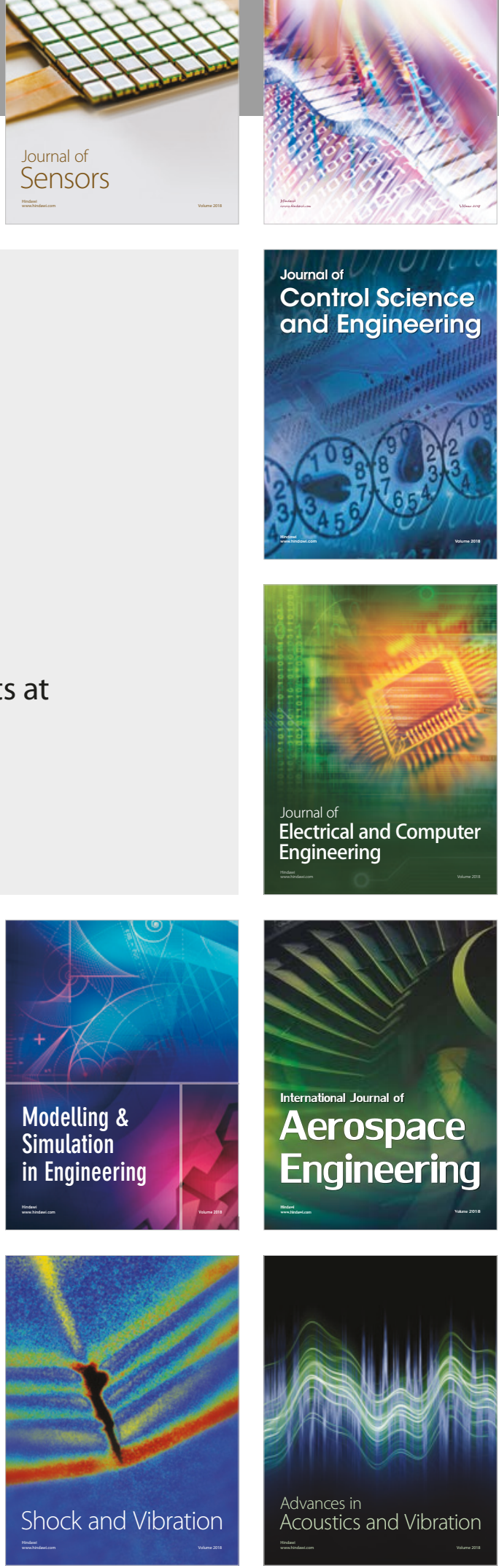